\title{
INNOWACJE GLOTTODYDAKTYCZNE
}

\author{
Iwona Janowska* \\ iD https://orcid.org/0000-0001-5133-2660
}

\section{ZADANIOWA KONCEPCJA KSZTAŁCENIA JEZYKOWEGO W MATERIALACH DO NAUCZANIA JEZZYKA POLSKIEGO JAKO OBCEGO}

Słowa kluczowe: materiały dydaktyczne, zadanie, podejście zadaniowe, nauczanie języków obcych, nauczanie języka polskiego jako obcego

Streszczenie. Pod koniec minionego stulecia w ramach metodologii komunikacyjnej zrodziła się potrzeba dostosowania systemu nauczania języków obcych do wymogów zmieniającej się rzeczywistości. Europejski system opisu kształcenia językowego Rady Europy (2003) zaprezentował nową wizję komunikacji i nowe ujęcie kompetencji użytkowników języka: komunikacja jest działaniem. Stąd zrodziło się pojęcie podejścia ukierunkowanego na działanie. W podejściu tym zaproponowano specyficzny sposób rozwijania sprawności komunikacyjnych, który polega na wykonywaniu zadań osadzonych w kontekstach środowiskowych i sytuacyjnych. Zasady nauczania i uczenia się zadaniowego od kilku lat przenikają do dydaktyki języka polskiego jako obcego. Niestety, mimo dość dobrze rozbudowanej bazy teoretycznej podejścia ukierunkowanego na działanie i zadaniowego brak jest nadal kompleksowych materiałów praktycznych i podręczników, które rozpropagowałyby założenia europejskiej polityki językowej w glottodydaktyce polonistycznej.

Artykuł pokazuje, jak zastosować podejście zadaniowe w praktyce pedagogicznej. Zaprezentowana zostanie koncepcja podręczników zadaniowych, powstających w Centrum Języka i Kultury Polskiej w Świecie Uniwersytetu Jagiellońskiego, która wpisuje się w najnowsze tendencje współczesnej glottodydaktyki. Odpowiada ona potrzebie uczenia języka żywego, autentycznego, który jest przede wszystkim narzędziem do wykonywania rozmaitych zadań o charakterze społecznym.

*iwona.janowska@uj.edu.pl, Uniwersytet Jagielloński, Wydział Polonistyki, Katedra Języka Polskiego jako Obcego, ul. Grodzka 64, 31-044 Kraków. 


\section{WPROWADZENIE}

O zadaniach i ich wykorzystaniu w procesie nauczania i uczenia się języka napisano już dużo, co świadczy o niesłabnącej aktualności i randze problemu. Dydaktycy prześcigają się w tworzeniu definicji i interpretacji pojęcia 'zadanie', mówią o typach, elementach składowych, sposobach prawidłowego konstruowania zadań oraz o ich zastosowaniu w praktyce pedagogicznej (zob. np. Ellis 2003; Nunan 2004; Willis, Willis 2007; Samuda, Bygate 2008). Za bogactwem refleksji teoretycznych nie nadąża jednak praktyka i mimo powszechnej znajomości zasad podejścia opartego na wykonywaniu zadań, tworzenia zadań, ich obecność w materiałach nauczania i salach lekcyjnych pozostawia wiele do życzenia. Nauczanie języka polskiego jako obcego nie stanowi tu wyjątku, chociaż potrzeby na tym polu zarysowują się znacznie wyraźniej niż w przypadku innych języków obcych.

Niniejszy artykuł jest próbą interpretacji zadaniowej koncepcji nauczania przez pryzmat praktyki. Poprzez przykłady wykorzystania różnego typu zadań w działaniach podejmowanych przez nauczyciela i uczniów w sali lekcyjnej staramy się pokazać, na czym w istocie polega metodyka zadaniowa, jak prawidłowo przebiega proces nauczania i uczenia się oparty na wykonywaniu zadań oraz jak można stosować zadania w materiałach nauczania. We wstępnej części artykułu dokonano ogólnej charakterystyki podejścia zadaniowego, ze szczególnym uwzględnieniem typów zadań, roli celów, rezultatu zadania oraz etapów realizacji zadań na zajęciach z języka obcego. Prezentacja tych zagadnień teoretycznych umożliwiła nakreślenie tła i wprowadzenie do dalszych rozważań na temat ich zastosowania w materiałach dydaktycznych - podręcznikach do nauczania języka polskiego jako obcego - RAZEM po polsku1 . Przedmiot szczegółowych analiz stanowią treści jednej jednostki metodycznej z pierwszej części serii, przeznaczonej dla poziomu A2.

\section{ZADANIE JAKO DZIALANIE UCZENIA SIE}

Początki zadaniowej koncepcji nauczania związane są z kształceniem zawodowym: realizacja zadania, a więc wykonanie jakiegoś dzieła (np. przedmiotu, urządzenia), była dowodem na to, że uczeń nabył już podstawowe umiejętności i kompetencje niezbędne do wykonywania danego zawodu. Zainteresowanie zadaniem w nauczaniu języków obcych wywodzi się z badań anglosaskich.

${ }^{1}$ Seria podręczników zadaniowych RAZEM po polsku powstała w Centrum Języka i Kultury Polskiej w Świecie UJ i obejmuje w chwili obecnej dwa tomy przeznaczone dla poziomów A2 i B1; autorem koncepcji dydaktycznej podręcznika i układu jednostek metodycznych jest I. Janowska. 
Task-Based Language Teaching (TBLT) to odmiana podejścia komunikacyjnego skoncentrowanego nie na produkcie (np. wypowiedzi ustnej, rozumieniu tekstu, itp.), lecz na procesie. Koncepcja ta zakłada, że przyswajanie języka zachodzi wówczas, gdy w klasie mają miejsce odpowiednie procesy interakcji pomiędzy uczącymi się. Aby mogły one zaistnieć, należy zastosować specjalnie zaprojektowane zadania instruktażowe, które kładą nacisk na znaczenie i autentyczną komunikację. Niewątpliwie należy stwierdzić, że zadania wykorzystywane są także $\mathrm{w}$ innych metodach lub podejściach, ale podejście zadaniowe traktuje je jako podstawową jednostkę nauczania i uzasadnia ich użycie. W nauczaniu należy stworzyć taki kontekst, sytuacje, okoliczności, które będą stymulowały naturalną zdolność uczenia się uczniów.

\subsection{DEFINICJE ZADANIA}

Czym jest zadanie? Na to pytanie udzielono już szereg odpowiedzi (zob. np. Janowska 2011, 2019), jednakże niezbędne wydaje się tutaj przypomnienie kilku zasadniczych właściwości zadania, do których należy się odwołać w perspektywie dalszych analiz materiału podręcznikowego.

W literaturze przedmiotu spotykamy się z wieloma definicjami zadań, a te mają różne podstawy teoretyczne. Jedna z pierwszych definicji została stworzona przez N.S. Prabhu (1987), który bazując na wynikach badań przeprowadzonych w ramach projektu Bangalore Project (1979-1984), zauważa, że rozwój kompetencji komunikacyjnej w języku obcym nie jest zależny od systematyzacji materiału językowego i intensyfikacji sterowanego użycia nowych struktur, lecz od specyficznych warunków nauczania polegających na rozwiązywaniu problemu (problem solving), które angażują uczących się w działania i wymagają pewnego wysiłku. W tej perspektywie zadanie jawi się jako narzędzie, które umożliwia działanie wymagające od uczniów osiągnięcia pewnego rezultatu na podstawie podanych informacji w toku procesów myślowych (Prabhu 1987, s. 24). Michael Long (1985, s. 89) w swojej definicji zadania kładzie nacisk na jego związek z czynnościami życia codziennego i podkreśla powszechność występowania zadań. Jest to praca podjęta dla siebie lub dla innych, wynagradzana lub nie. David Nunan podaje definicję zadania komunikacyjnego, które wymaga użycia języka: to praca w klasie, która angażuje uczniów w zrozumienie, produkcję lub interakcję w języku docelowym, podczas gdy ich uwaga skupia się głównie na znaczeniu, a nie formie (Nunan 2004, s. 4). Z kolei Jane Willis (1996, s. 23) podkreśla, że zadaniem jest działanie zorientowane na cel, podczas którego uczący się używa języka docelowego dla osiągnięcia zakładanego rezultatu. W definicji Petera Skehana (1998, s. 95) zadanie to czynność ukierunkowana na znaczenie, rozwiązywanie problemów komunikacyjnych, które 
nawiązują do czynności wykonywanych w sytuacjach realnych, życiowych; wykonie zadania stanowi priorytet, a osiągnięcia ucznia oceniane są pod względem stopnia jego wykonania. W tej definicji priorytetem jest wykonanie zadania mierzone poprzez rezultat. Michael Breen rozumie zadanie jako szereg planów pracy, których ogólnym celem jest ułatwienie nauki języka - od prostych i krótkich ćwiczeń po bardziej złożone i długotrwałe działania, takie jak grupowe rozwiązywanie problemów lub symulacje i podejmowanie decyzji (Breen 1987, s. 23).

M. Bygate, P. Skehan i M. Swain, przedstawiając definicje zadania wywodzące się od wielu badaczy², wyjaśniają, że muszą one być różne w zależności od celów, do których są wykorzystywane. Autorzy proponują jednocześnie podstawową, wszechstronną definicję, według której zadanie jest działaniem wymagającym od uczniów użycia języka, z naciskiem na znaczenie, ukierunkowanym na osiągnięcie celu (Bygate i in. 2001, s. 11).

Definicje zadania stworzone przez badaczy Task-Based Language Teaching stały się inspiracją dla twórców Europejskiego systemu opisu kształcenia językowego, gdzie poświęcono temu zagadnieniu wiele miejsca (rozdział 7.). Definiuje się je jako „każde celowe działanie, uważane za konieczne, by rozwiązać jakiś problem, wypełnić zobowiązanie lub zrealizować dążenie" (ESOKJ 2003, s. 21). Jest ono działaniem o charakterze społecznym, „uwarunkowanym kontekstem środowiskowym i sytuacyjnym” (ESOKJ 2003, s. 20) i zmierza do ,jasno określonego celu i konkretnego wyniku" (ESOKJ 2003, s. 136).

Jak wynika z przytoczonych tu definicji zadania, badacze interpretują to pojęcie na wiele sposobów, podają mniej lub bardziej szczegółowe opisy, w których powtarzają się te same parametry: zadanie jest działaniem podejmowanym w ściśle określonym celu, realizowanym przy użyciu języka docelowego i zakończonym zakładanym, identyfikowalnym re zult a te m; język jest postrzegany nie jako cel sam w sobie, ale jako narzędzie umożliwiające osiągnięcie celu - stąd koncentracja przede wszystkim na znaczeniu, a dopiero w drugiej kolejności na poprawności użytych form. Wykonanie zadania wymaga uruchomienia określonych procesów poznawczych.

\subsection{TYPY ZADAŃ}

Kolejny problem, który pojawia się w refleksji nad zadaniami, to ich klasyfikacja. Autorzy ESOKJ dzielą zadania na dwie zasadnicze kategorie: zadania o charakterze pedagogicznym (pedagogical task) oraz zadania „z życia wzięte” (real-world tasks). Zadania pedagogiczne tworzone są dla potrzeb kształcenia ję-

${ }^{2}$ m.in. M. Longa (1985), G. Crookesa (1986), N.S. Prabhu (1987), D. Nunana (1989), J. Carrolla (1993), J. Willis (1996), L. Bachmana i A. Palmera (1996). 
zykowego, w trakcie którego uczniowie „chętnie angażują się w nieco sztuczną sytuację i godzą się na posługiwanie się językiem docelowym” (ESOKJ 2003, s. 136). Wymagają zastosowania strategii interakcyjnych i nastawione są na użycie konkretnych elementów języka lub ćwiczonej aktualnie umiejętności. Takie zadanie nie może zostać uznane za autentyczne, ponieważ w naturalnej komunikacji nie skupiamy się tylko na wybranym aspekcie języka. Jednakże procesy interakcji, w które angażują się uczący się, aby wykonać zadanie, stanowią podstawy do autentycznego użycia języka w przyszłości. Z kolei zadania ,z życia wzięte" - autentyczne to takie, z którymi spotykamy się w codziennej rzeczywistości - dobierane na podstawie pozaszkolnych potrzeb uczących się lub kontekstu nauczania. Odzwierciedlają one rzeczywiste użycie języka i mogą być rozumiane jako próba autentycznej komunikacji, pomagająca uczącym się w przygotowaniu do działania poza klasą językową (por. Richards 2006, s. 31).

Odmienną kategorię, choć ściśle związaną z pojęciem zadania, stanowią ćwiczenia językowe. Uaktywniają one wiedzę i umiejętności uczniów oraz poszerzają je o nowe elementy, niezbędne do prawidłowego przebiegu procesu uczenia się, do rozwijania kompetencji językowych, stosownie do sytuacji komunikacyjnej. Tworzą one swoistą bazę treściową, złożoną z repertuaru słów i form gramatycznych, w ramach której uczący się podejmuje działania językowe i wykonuje zadania. Zadania i ćwiczenia nie wykluczają się, lecz współwystępują w procesie realizacji zadań. Prawidłowa realizacja zadań wymaga odwoływania się do ćwiczeń. Zadania (pedagogiczne i autentyczne) służą do rozwijania kompetencji - ogólnych i językowych oraz umiejętności szczegółowych. Natomiast ćwiczenia są odpowiedzialne za mechaniczne uczenie się i utrwalanie form językowych, które z kolei zostaną uruchomione w kontekście językowym i społecznym.

Zadania można również klasyfikować według stopnia ich złożoności. „Zadanie może być proste lub bardzo złożone [...]. Dane zadanie może składać się z większej lub mniejszej liczby etapów albo zadań cząstkowych, co może się wiązać z trudnością określenia granic poszczególnych zadań" (ESOKJ 2003, s. 136). Zadanie złożone, lub inaczej makrozadanie, zawiera zadania cząstkowe, które badacze nazywają mikrozadaniami, podzadaniami, a także etapami (ESOKJ 2003; Demaizière, Narcy-Combes 2005; Nissen 2011). Każde podzadanie (lub inaczej etap, mikrozadanie, zadanie cząstkowe) jest bezpośrednio zorientowane na realizację zadania końcowego - makrozadania, nazywanego również głównym.

\subsection{CEL I REZULTAT ZADANIA}

Zaprezentowane powyżej definicje potwierdzają, że zadania powinny mieć wyraźnie określony cel, a także rezultat. W podejściu zadaniowym cele te mogą być celami uczenia się, takimi jak rozwijanie umiejętności uczniów, lub mogą 
stanowić osobiste konkretne dążenia uczących się. W praktyce pedagogicznej często cel utożsamiany jest $\mathrm{z}$ rezultatem zadania. Jednak w dydaktyce zadaniowej należy rozróżnić cel zadania od jego wyniku. Cel powinien uwzględniać pedagogiczne zamierzenia kształcenia językowego, np. rozwój umiejętności mówienia, a wynik/rezultat powinien dotyczyć konkretnego ,produktu” danego zadania, np. opisywanie drogi do centrum miasta. Język, mający postać określonego działania językowego (recepcji, produkcji, interakcji czy mediacji), służy jako środek osiągania rezultatu, który jest inny niż samo użycie języka.

Zatem działanie uczenia się bez uprzedniego wyznaczenia celu jest bezowocne, uczeń/student nie wie, dokąd zmierza, a więc nie potrafi dokonać wyboru środków zapewniających jego pomyślną realizację, zwłaszcza jeżeli musi samodzielnie stawić czoła wyzwaniu i podejmować decyzje związane z realizacją zadań. Chociaż cel był zawsze pojęciem pierwszoplanowym, można śmiało stwierdzić, że chyba nigdy dotąd $\mathrm{w}$ dydaktyce językowej nie przypisywano mu tak wielkiej wagi (jego wyznaczaniu, definiowaniu i realizacji), jak to ma miejsce w podejściu zadaniowym. Uczenie się przez wykonywanie zadań to działanie w dużej mierze samodzielne - a więc cel to drogowskaz dla uczącego się, by nie pogubił się na drodze rozwijania swych kompetencji komunikacyjnych. Dlatego w nauczaniu opartym na wykonywaniu zadań precyzowanie, definiowanie, uświadamianie sobie celów zaliczane jest do uwarunkowań decydujących o sukcesie uczniów w przyswajaniu języka. Właściwie postawiony cel to kierunek działań, a jego osiągnięcie/rezultat to feed back - retrospekcja przebytej drogi (działań zarówno efektywnych, jak i nieprawidłowych) i formułowanie wniosków na przyszłość. Cele są osią działań każdego uczenia się, szczególnie w podejściach pozostawiających zainteresowanym duży margines swobody działań pedagogicznych.

\subsection{KONCENTRACJA NA ZNACZENIU I KONCENTRACJA NA FORMIE}

Jak pokazują przywołane definicje, zadanie zakłada działanie skoncentrowane na znaczeniu (focus on meaning). Jedną z głównych funkcji zadania jest rozwijanie biegłości językowej w trakcie komunikacji i poprzez angażowanie uczących się w autentyczne użycie języka. $Z$ tego powodu zadanie powinno zwierać „lukę”, czyli potrzebę komunikowania konkretnych informacji. Wypełnienie tej luki stanowi motywację do użycia języka, lecz aby wykonać zadanie, trzeba posługiwać się zasobami językowymi i pozajęzykowymi. Ramy zadania nie określają szczegółowo, jakich form należy użyć i pozwalają na wybór takich struktur, które pomogą zrealizować cel zadania. Nie oznacza to jednak zupełnej dowolności, gdyż tematyka zadania zawęża wybory do określonych pól semantycznych oraz tworzy 
potrzebę uruchomienia określonych procesów myślowych, co łączy się z określonymi możliwościami językowymi (Ellis 2009, s. 223). Zadanie ukierunkowuje uczących się w stronę użycia pewnych form językowych, jednak ostateczny ich wybór należy do wykonujących zadanie. Tu rodzi się pytanie: skąd uczący się będzie czerpał odpowiednie konstrukcje językowe, aby móc działać? Jakiego typu czynności pomogą mu w opanowaniu podsystemów języka?

Za rozwój środków językowych odpowiedzialne są innego typu zadania - skoncentrowane na formie (focus on form) $)^{3}$, stosowane w szerokim zakresie w podejściu zadaniowym w różnych fazach lekcji. Koncentracja na formie zakłada eksplicytne odwoływanie się do danej struktury pojawiającej się w analizowanym tekście lub wykonywanym zadaniu. Można angażować uczących się $\mathrm{w}$ poszukiwania $\mathrm{w}$ ich repertuarze językowym struktur, które najlepiej oddają przekazywane znaczenia w danej sytuacji komunikacyjnej.

Teoretycy podejścia zadaniowego różnie nazywają i opisują działania o charakterze językowym, sytuują je w różnych fazach procesu dydaktycznego. David Nunan wyszczególnia dwa rodzaje zadań: zadanie ogniskujące (focused task), do wykonania którego wymagana jest konkretna struktura oraz zadanie nieogniskujące (unfocused task), czyli takie, w którym uczący się mogą używać dowolnych dostępnych im środków językowych w celu jego ukończenia. W opinii badacza warianty te są komplementarne i mogą występować naprzemiennie w procesie dydaktycznym (Nunan 2004, s. 94). Rod Ellis wprowadza dodatkową kategorię, którą określa jako zadania zwiększające świadomość językową (consciousness-raising tasks). Są to zadania zaprojektowane tak, by zapewnić eksplicytne uczenie się, a ich rolą jest uświadomienie sposobów funkcjonowania określonych zjawisk językowych. Badacz rozszerza pojęcie zadania także na działania wymagające bezpośredniej koncentracji uwagi na zagadnieniach językowych. Podkreśla również konieczność dostarczenia uczącemu się materiału ilustrującego funkcjonowanie danej formy/struktury w kontekście oraz tworzenie zadań w taki sposób, aby uczący się musieli dokonać szeregu operacji na danych wejściowych w celu zrozumienia określonego zjawiska oraz (niekiedy) także samodzielnego opracowania reguły (Ellis 2003, s. 163-164). Dave i Jane Willis również dostrzegają potrzebę nauczania struktur językowych w metodyce zadaniowej. Służą temu

\footnotetext{
${ }^{3}$ Autorem koncepcji, która na nowo zdefiniowała określenie focus on form, jest Michael Long (1991). Zaproponował on odmienne od wcześniej istniejących definiowanie tego pojęcia, oddzielając tzw. focus on form $S$ - rozumiane jako tradycyjne podejście do roli i sposobu nauczania gramatyki, oparte na programach syntaktycznych i skoncentrowane w pierwszej kolejności na strukturach językowych od focus on form - koncepcji nauczania opartej na programach analitycznych, skupionych wokół celów komunikacyjnych, do realizacji których konieczne są jednak określone środki językowe, mimo że uwaga uczących się kierowana jest najpierw na znaczenie. W tym sensie koncepcja focus on form przypomina podejście focus on meaning, ale nie jest z nim tożsama, bowiem w procesie odkrywania znaczenia umożliwia także refleksję nad formą (zob. Janowska, Rabiej 2014).
} 
zadania zwiększające świadomość językową (consciousness-raising tasks) czy też zadania metakomunikacyjne (metacommunicative tasks), których celem jest przede wszystkim opanowanie danej formy językowej. Badacze ci wyróżniają trzy fazy realizacji sekwencji zadaniowej: (1) koncentracja na znaczeniu (focus on meaning), kiedy to uczestnicy są skupieni na komunikacji; (2) koncentracja na języku (focus on language), gdy w trakcie działań skoncentrowanych na znaczeniu użytkownicy języka zastanawiają się, jak najlepiej wyrazić to, co chcą powiedzieć lub kiedy nauczyciel wchodzi w interakcję ze studentami i ułatwia proces uczenia się poprzez parafrazowanie i precyzowanie języka uczniów; (3) koncentracja na formie (focus on form), kiedy dana forma leksykalna czy gramatyczna zostaje wyizolowana i poddawana analizie (Willis, Willis 2007, s. 5). Natomiast D. Nunan proponuje, aby sekwencja zadaniowa składała się z sześciu faz, przy czym część ściśle poświęcona strukturom językowym to faza czwarta. Ostatnim ogniwem całego procesu jest (bardziej lub mniej kompleksowe) zadanie główne. Przed jego realizacją uczący się zostają wprowadzeni w tematykę i kontekst, dokonują rozmaitych operacji na dostarczonym materiale, poznają niezbędne słownictwo i struktury (Nunan 2004, s. 31-33).

W podejściu zadaniowym język postrzegany jest jako narzędzie przekazywania znaczenia, bowiem podczas autentycznej komunikacji użytkownicy języka skupiają się najczęściej na przekazaniu informacji, w nadziei, iż rozmówca będzie w stanie zrozumieć znaczenie przekazywanego komunikatu. Ich wypowiedzi mają charakter eliptyczny, gdyż w codziennej komunikacji przekazywane znaczenie jest potrzebą nadrzędną w stosunku do posługiwania się pełnymi, poprawnie skonstruowanymi zdaniami. Nie znaczy to jednak, że zadania powinny ignorować konieczność utrwalania przez uczących się poprawnych form językowych.

\subsection{FAZY REALIZACJI ZADAŃ}

Każde zadanie jest małym ogniwem w szeroko pojętym procesie uczenia się, a etapy jego realizacji odpowiadają fazom akwizycji języka obcego. Schematy realizacji zadań różnią się zarówno liczbą faz, jak i stopniem szczegółowości opisu. Jednakże większość modeli zawiera trzy podstawowe etapy: działania przed, w trakcie i po wykonaniu zadań (zob. np. Willis 1996; Skehan 1998; Ellis 2006, 2009).

Faza pierwsza - pre-task, jak wskazuje sama nazwa, ma miejsce przed przystąpieniem zespołu do realizacji zadania. Jest to wprowadzenie do tematyki i do zadania. Nauczyciel przygotowuje uczących się do wykonania zadania głównego przy pomocy działań wstępnych, zadań cząstkowych, ćwiczeń i instrukcji. Istnieje wiele rozmaitych sposobów, metod i technik wyczulenia uczących się na tematykę i treści zadania głównego - mogą oni np. wysłuchać nagrania, prze- 
czytać tekst o treści podobnej do tej, nad którą będą pracować lub wykonać ćwiczenia mające na celu aktywizowanie potrzebnych środków językowych (Willis 1996; Willis, Willis 2007). N. S. Prabhu z kolei proponuje, aby w tej fazie uczący się wykonali wraz z nauczycielem zadanie podobne do zadania głównego. Autor podkreśla rolę nauczyciela-przewodnika, który krok po kroku prowadzi swych podopiecznych do pożądanego rezultatu i upewnia się, czy każdy rozumie, jakie umiejętności są niezbędne do prawidłowego wykonania zadania (Prabhu 1987). Inną czynnością $\mathrm{w}$ tej części sekwencji zadaniowej jest planowanie wypowiedzi (Skehan 1998), które może wpływać zarówno na jakość produkcji językowej (płynności i poprawność tworzonych tekstów), jak i na ogólne powodzenie w wykonywaniu zadań. Uwaga obu uczestników procesu dydaktycznego - nauczyciela i uczniów - skoncentrowana jest na uaktywnieniu wiedzy i umiejętności uczących się, na zmotywowaniu tych ostatnich do pracy nad zadaniem.

Faza realizacji zadania - task ${ }^{4}$ - to praktyczne użycie języka i przekazywanie znaczeń w trakcie wykonywania zadania głównego. Poza refleksją nad tematem i poszukiwaniem środków językowych może również obejmować zaangażowanie uczących się w przygotowanie się do wykonania zadania: ustalenie planu działania, redagowanie różnego rodzaju kwestionariuszy, propozycje pytań do dyskusji, powtórzenie elementów przyswojonych w trakcie poprzednich zajęć, opracowanie planu sprawozdania etc. Według D. i J. Willis (2007) faza ta może składać się $\mathrm{z}$ trzech etapów: zadanie (task), planowanie prezentacji (planning a report) oraz przekazanie informacji zwrotnej (reporting back) ${ }^{5}$. W trakcje lub po wykonaniu zadania, pracując $\mathrm{w}$ parach lub kilkuosobowych zespołach, uczniowie przygotowują sprawozdanie ustne lub pisemne z realizacji zadania, odnotowują własne obserwacje, decyzje i uwagi. Następnie przystępują do prezentacji wykonanego zadania. Rezultat zadania może mieć postać wypowiedzi, exposé, debaty, broszury, nagrania, plakatu etc. Wymiana informacji i porównywanie wyników następuje w podgrupach lub na forum całego zespołu.

Kolejna sekwencja - post-task - to czynności końcowe poświęcone analizie procesu realizacji zadania. Jej celem jest często doskonalenie umiejętności językowych uczących się tak, aby mogli bardziej precyzyjnie formułować wypowiedzi w języku obcym. Dla J. i D. Willis (2007) jest to etap pracy nad językiem, podczas którego ma miejsce analiza cech języka docelowego i objaśniania (analysis) oraz praktyczne ćwiczenia językowe (practice). Faza ta obejmuje czynności zwiększające świadomość językową, w trakcie której nauczyciel zwraca uwagę uczniów na formy ważne z perspektywy wykonania zadania lub nawiązuje do wcześniejszych wypowiedzi uczniów. Następnie uczniowie wykonują ćwiczenia automatyzujące słownictwo, struktury gramatyczne czy funkcje istotne dla uczniów. Ostatnim

\footnotetext{
${ }^{4}$ Nazywane również: while-task (Ellis 2003, 2006, 2009), task-cycle (Willis 1996).

${ }^{5}$ Porównaj wcześniejszy model J. Willis (1996): 1. Pre-task: introduction to topic and task; 2. Task cycle: task, planning, report; 3. Language focus: analysis, practice.
} 
etapem pracy nad zadaniem jest powtórzenie i/lub ocena zadania (task repetition and/or evaluation). Uczący się mogą ponownie wykonać zadanie, poprawiając tym samym swoją skuteczność komunikacyjną. Faza pozadaniowa bywa niekiedy w całości poświęcona analizie wypowiedzi uczniów i pracy nad pojawiającymi się problemami.

Przedstawiony schemat możemy uznać za rodzaj klarownego, uproszczonego planu prezentującego krok po kroku typ oraz kolejność działań nauczyciela i studentów. Jakkolwiek dydaktyka jest sama w sobie kreatywna i nie toleruje sztucznych barier, przestrzeganie takiej sekwencji działań jest warunkiem sprawnej organizacji procesu uczenia się przez wykonywanie zadań i ma bezwzględnie wpływ na osiągane wyniki.

\section{KONCEPCJA SERII PODRĘCZNIKÓW ZADANIOWYCH RAZEM PO POLSKU}

W opinii twórców ESOKJ podejście zadaniowe jest jednym z „,najlepiej rozwiniętych i w ostatnich latach najchętniej podejmowanych zagadnień z dziedziny kształcenia językowego" (ESOKJ 2003, s. 9), co długo nie znajdowało odzwierciedlenia w metodyce nauczania języka polskiego jako obcego.

Seria podręczników RAZEM po polsku w swojej koncepcji wpisuje się w najnowsze europejskie trendy w nauczaniu / uczeniu się języków obcych - są to materiały dydaktyczne opracowane $\mathrm{w}$ duchu podejścia opartego na wykonywaniu zadań. Ich zasadniczym celem jest przygotowanie językowe, komunikacyjne i społeczne do wykonania różnego rodzaju zadań „z życia wziętych”.

Podręczniki oraz towarzyszące im zeszyty ćwiczeń są adresowane do młodzieży i dorosłych uczących się języka polskiego jako obcego na poziomach A2 i B1 ${ }^{6}$. Każdy z nich składa się z 10 jednostek metodycznych (rozdziałów) o podobnej strukturze, a zawarte w nich treści przygotowują sukcesywnie, po pierwsze, do osiągnięcia wyznaczonego celu końcowego jednostki, tj. realizacji zadania głównego (makrozadania) o charakterze społecznym, po drugie, perspektywicznie, do wykonywania zadań przy użyciu języka docelowego w rzeczywistości pozaszkolnej.

Na wstępnej - pierwszej stronie każdej jednostki metodycznej podręczników zamieszczono informację, jakie zadanie główne jest celem działań dydaktycznych oraz wyjaśniono kolejne kroki prowadzące do jego realizacji. W kolejnej części

${ }^{6}$ D. Bednarska, J. Machowska, U. Majcher-Legawiec, A. Rabiej, 2020, RAZEM po polsku. Podręcznik do nauki języka polskiego jako obcego. Poziom A2, Kraków [w druku]; D. Bucko, A. Prizel-Kania, D. Rogala, 2020, RAZEM po polsku. Podręcznik do nauki języka polskiego jako obcego. Poziom B1, Kraków [w druku]. 
zatytułowanej „Teksty, konteksty, działania” uczący się stykają się z konkretnymi formami językowymi w kontekście, zachęcani są do działań zbliżonych do tych, które mają miejsce w rzeczywistości pozaszkolnej. Kolejna część - „Formy i reguły" umożliwia usystematyzowanie wprowadzonych struktur leksykalno-gramatycznych, często niezbędnych do realizacji zadania głównego. Zawiera ona zestawienia i ćwiczenia leksykalne, także reguły gramatyczne i przykłady ich stosowania. Następnie proponuje się nowy kontekst komunikacyjny, w którym uczący się powtórnie używa elementów przyswojonych w poprzedzających etapach. Realizacja zadania głównego stanowi podsumowanie procesu uczenia się i potwierdzenie nabycia konkretnych umiejętności. Sekcja jednostki zatytułowana „Między kulturami” to zbiór różnego typu tekstów, materiałów ikonograficznych i zadań związanych z tematyką jednostki, które służą kształceniu międzykulturowej kompetencji komunikacyjnej, pogłębieniu znajomości polskiej kultury. Jednostka metodyczna kończy się tabelą samooceny, dzięki której uczący się mogą zweryfikować stopień realizacji zakładanych celów, sygnalizowanych na pierwszej stronie jednostki. Po niej zamieszczono ciekawostki o charakterze językowo-kulturowym

\section{ZADANIOWE PARAMETRY JEDNOSTKI PODRĘCZNIKOWEJ RAZEM PO POLSKU. POZIOM A2}

Obserwacji struktury zadań oraz proponowanej ich realizacji dokonano na konkretnym materiale językowym stanowiącym treść rozdziału ósmego podręcznika RAZEM po polsku. Poziom A2. Temat ogólny tej jednostki metodycznej to PODRÓŻE I PODRÓŻOWANIE.

\subsection{CELE I REZULTAT ZAJĘĆ}

Jak wspomniano powyżej (zob. 2.3.), jednym z zasadniczych elementów pracy dydaktycznej w ogóle, a w podejściu zadaniowym w szczególności, jest wyznaczenie celów i uświadamianie ich uczącym się. „Uczniowie bardziej interesują się lekcją i mają większą ochotę w niej uczestniczyć, jeżeli znają cele, są merytorycznie przygotowani do podjęcia pracy nad danym materiałem i rozumieją instrukcje nauczyciela" (Kruszewski 2005, s.126).

W omawianym podręczniku cele nauczania i uczenia się umieszczono w sposób eksplicytny na pierwszej stronie otwierającej każdy z rozdziałów i podzielono je na społeczno-kulturowe, komunikacyjne i językowe: 


\section{Tytuł rozdziału: PodróżuJeMY BLISKo I DALEKo}

Aby osiągnąć ten cel, musimy:

Dowiedzieć się:

- co to jest „długi weekend” w Polsce i jak można go zaplanować,

- jakie są w Polsce miejsca ciekawe do zwiedzania i wypoczynku.

Nauczyć się:

- czytać i rozumieć proste teksty informacyjne,

- wyrażać opinię, przyjmować i odrzucać propozycje dotyczące spędzania wol-

nego czasu,

- wybierać miejsce wypoczynku i rezerwować noclegi,

- planować pobyt,

- redagować proste teksty nieformalne (wpis na portalu społecznościowym).

Umieć używać:

- słownictwa związanego z podróżami, środkami transportu, opisem osób, miejsc, czynności,

- form trybu przypuszczającego.

Wyżej wymienione umiejętności są - konsekwentnie - przedmiotem samooceny przewidzianej na końcu jednostki (w postaci tabeli), zawierającej sformułowania: „wiem”, „potrafię”, „używam”.

Kolejnym, bardzo ważnym z punktu widzenia dydaktyki zadaniowej elementem przygotowania uczących się do pracy jest określenie r e zulta tu, jaki uczniowie powinni osiągnąć - czyli zadania głównego. Rezultat zadania jest nadrzędny w stosunku do celów. W rozdziale 8. podręcznika jest to OrGANIZACJA WYCIECZKI DLA KILKU OsÓB. Informacja na temat zadania głównego wskazuje uczącym się, co będą umieli wykonać, jakich praktycznych umiejętności nabędą, realizując - wyszczególnione i opisane w kategoriach czynnościowych - cele.

Pierwsza strona jednostki ma nieco osobliwy charakter: określa cele kształcenia językowego i rezultat zadania. Nie zawiera tekstów (poza krótkimi pojedynczymi napisami), ćwiczeń czy poleceń. Wypełnia ją natomiast seria tematycznie powiązanych ilustracji, zdjęć, rysunków etc. Tworzą one istotny etap poprzedzający wykonywanie zadań (pedagogicznych i „z życia wziętych”), ponieważ aktywizują nabytą już wiedzę i umiejętności uczących się. Elementy wizualne stanowią bodziec do refleksji, wywołują rozmaite skojarzenia w zależności od doświadczenia życiowego i językowego uczestników kursu. Poza tym wzmacniają uwagę uczących się i wyzwalają chęć aktywnego uczestnictwa w lekcji, jednym słowem - podnoszą motywację.

Reasumując: zaproponowane rozwiązania i czynności dydaktyczne zawarte na stronie otwierającej rozdział umożliwiają uświadomienie celów nauczania i rezultatu podejmowanych przez uczących się wysiłków, antycypację treści nauczania, wyczulenie na tematykę zajęć i zaktywizowanie grupy. 


\subsection{ZADANIA PEDAGOGICZNE I „Z ŻYCIA WZIĘTE”}

W literaturze przedmiotu poświęconej zadaniom znajdujemy szereg ich klasyfikacji (zob. Willis 1996; Richards i Rodgers 2001; Nunan 2004; Richards 2006). Z perspektywy nauczania zadaniowego ważne jest przyjęcie jakiejś, choćby najprostszej typologii. Autorki RAZEM po polsku. Poziom A2 mają pełną świadomość ustaleń terminologicznych i prezentują szeroką gamę różnorodnych zadań - mniej lub bardziej kompleksowych, mniej lub bardziej autentycznych - oraz ćwiczeń (zob. 2.2.). Zadania znajdujemy przede wszystkim w części pt. „Teksty, konteksty, działania” oraz sekcji „Między kulturami”, gdzie ich rolą jest zasadniczo tworzenie wiedzy, kształcenie umiejętności oraz rozwijanie międzykulturowej kompetencji komunikacyjnej. Ćwiczenia są domeną części jednostki metodycznej zatytułowanej „Formy i reguły”.

W przeprowadzanych analizach zadań zwracano szczególną uwagę na polecenie, które ukierunkowuje działania uczących się - w nim jest zawarty cel, jaki przyświeca podejmowanym czynnościom. Podczas gdy w nauczaniu tradycyjnym spotykamy najczęściej polecenie typu: „Przeczytaj tekst(y) i odpowiedz na pytania", w analizowanej jednostce kładzie się nacisk na celowość czytania. Na przykład: uczestnik czatu - makoschako ma pewien problem i nie wie, jak go rozwiązać:

MAKOSCHAKO: Cześć! Szukam inspiracji... Chciałbym pojechać ze znajomymi na wycieczkę, ale nie za bardzo wiem dokąd. Moglibyście coś polecić?

Po tym wpisie zamieszczono odpowiedzi, a raczej podpowiedzi kilku osób:

PATRYK NAPISAE: Z kumplami byliśmy już w Bieszczadach, na Mazurach, a ostatnio na Kaszubach. Kaszuby są rewelacyjne! I jeziora, i lasy, i góry! Może nawet pojedziemy tam zimą, bo jest kilka wyciągów narciarskich.

MarTa NaPisaza: Też lubimy Kaszuby! Byliśmy tam niedawno. To takie „dwa w jednym”: chcieliśmy mieć spokój nad jeziorem - mieliśmy. Chcieliśmy poleżeć na plaży, pospacerować nad morzem, posłuchać szumu fal - pół godziny i byliśmy nad Bałtykiem. Gorąco polecam ten wariant.

JaNINA NAPISAEA: Dla mnie polskie morze nie jest atrakcyjne. Za dużo ludzi, zwłaszcza młodych i głośnych. W moim wieku ważniejsza jest cisza i kontakt z naturą. Zdecydowanie wolę góry. Ale nie Zakopane! Raczej Bieszczady, może Karkonosze. Zwłaszcza jesienią - to najlepszy czas na wypoczynek!

Itd.

Uczeń ma za zadanie przeczytać wypowiedzi uczestników czatu i powiedzieć, jakie propozycje mają dla makoschako. W analizowanym zadaniu (nr 2 w części „Teksty, konteksty, działania”) uczniowie zapoznają się z krótkimi tekstami i w nich znajdują inspiracje odnośnie do sposobów wyjścia z sytuacji. Czytanie 
nie jest celem samym w sobie, lecz narzędziem do rozwijania innych działań językowych, w tym wypadku mediacyjnych, polegających na przetwarzaniu tekstu, co z kolei umożliwia zaproponowanie pomocy i porady w zadaniu $3 .:$

Powiedz, dokąd ty chciałbyś/chciałabyś pojechać na weekend? Dlaczego? Dokąd na wycieczki najczęściej wyjeżdżają ludzie w twoim wieku?

W zadaniu 6. ponownie zachęca się uczniów do przeczytania krótkich tekstów, ale polecenie do nich również odbiega od klasycznego. Tym razem uczniowie odgrywają role turystów planujących pobyt w jakimś atrakcyjnym miejscu. Aby dokonać wyboru odpowiedniego miejsca, odwołują się do materiałów zamieszczonych w podręczniku (adaptowane informacje na temat różnych miejsc zakwaterowania, mapy, zdjęcia). Propozycji jest wiele, ale nie wszystkie są zadowalające: w ofertach brak niekiedy bardzo istotnych szczegółów np. na temat cen noclegów czy wyżywienia. Lektura teksu ma na celu nie tylko rozwijanie rozumienia selektywnego, ale również stwierdzenie, jakich ważnych informacji brakuje w opisie danych ośrodków turystycznych i odnotowanie ich w tabeli:

Utwórzcie trzy grupy. W grupach wybierzcie po dwie oferty różnych miejsc, które czekają na turystów i znajdźcie je na mapie Polski. Następnie:

- przeczytajcie te oferty i uzupełnijcie informacje w tabeli,

- zastanówcie się, jakich informacji brakuje w tych ofertach, które są ważne dla turysty przed decyzją o wyjeździe,

- zapiszcie te uwagi.

Przedyskutowanie ofert na forum i wybór najatrakcyjniejszej dla studentów to treść kolejnego zadania (zadanie 7.), którego polecenie brzmi:

Przedstawcie na forum wszystkie zalety ofert turystycznych, które analizowaliście. Wspólnie zadecydujcie, która z tych ofert jest najbardziej atrakcyjna $(* * * *)$, a która najmniej ciekawa $\left(^{*}\right)$ dla studentów. Uzasadnijcie swój wybór.

Zaproponowane $\mathrm{w}$ dalszej części jednostki zadania nie polegają już na rozumieniu tekstów, lecz zobowiązują do konkretnych działań i podejmowania decyzji w sprawie wyjazdu w góry. Trzeba wspólnie uzgodnić wiele spornych kwestii - nie na zasadzie biernej akceptacji czyjejś propozycji, ale poprzez wysuwanie argumentów i kontrargumentów, dążenie do uzyskania konsensusu poprzez negocjowanie. Rezerwacja noclegów i pakowanie bagażu (co warto zabrać i dlaczego) wymaga również dyskusji z kolegami w celu znalezienia najlepszego wyjścia; przygotowuje także - nie tylko językowo - do realizacji makrozadania (zob. 4.3.).

Niektóre z zaprezentowanych w jednostce zadań (np. zadanie 6. i 7.) to zadania zespołowe (occupational tasks), które mają na celu wymianę informacji/ znaczeń, ale również wymagają koordynowania działań, współpracy, negocjacji i wzajemnej motywacji członków grupy, a także umiejętności współdziałania z osobami o odmiennych stylach życia i poglądach. Rozwijają zatem kompetencje komunikacyjne (językowe, pragmatyczne, socjolingwistyczne) oraz kompetencje 
ogólne użytkowników języka (wiedzę, umiejętności, uwarunkowania osobowościowe, umiejętność uczenia się) i stanowią narzędzie szeroko rozumianej interakcji.

Na podstawie przywołanych przykładów można dostrzec cechy zadania, a co za tym idzie, łatwiej zrozumieć istotę metodyki zadaniowej. Realizacja zadań to działanie zorientowane na osiągnięcie określonego celu w sytuacjach zbliżonych do rzeczywistych, zakończone (często) konkretnym rezultatem. W wyżej opisanych przykładach mamy w większości do czynienia z zadaniami pedagogicznymi ukierunkowanymi na rozwijanie konkretnych działań (sprawności) językowych: receptywnych produktywnych, interakcyjnych oraz mediacyjnych (zadanie 2.). W każdym jednak przypadku nakreślono w poleceniu autentyczny szeroki kontekst użycia języka.

\subsection{ZADANIE GŁÓWNE (MAKROZADANIE) I JEGO REALIZACJA}

Każda jednostka metodyczna w podręczniku RAZEM po polsku. Poziom $A 2^{7}$ zakłada realizację jakiegoś kompleksowego zadania - makrozadania. Uczący się musi np.: opracować wpis na blog, wynająć mieszkanie, znaleźć dorywczą pracę, zorganizować grupowy wyjazd, przygotować informator o Polsce itp. W ramach danej jednostki zadanie główne wyznacza dobór treści językowych, tworzy kontekst, sytuacje, okoliczności, które będą stymulowały naturalną zdolność uczenia się. Jak już wielokrotnie podkreślano, podstawową cechą zadania jest jego ukierunkowanie na rozwiązywanie problemów; trudności, które uczący się muszą pokonać, pobudzają do inwencji i generują nowy sposób myślenia. To działanie opiera się na interakcjach między uczącymi się, którzy mają sobie coś do zakomunikowania. Jednakże mimo konkretnych, szczegółowych poleceń, każde zadanie ma charakter otwarty, tzn. pozostawia uczącym się dużą swobodę w jego rozwiązywaniu, w podejmowaniu działań zgodnie z własnymi możliwościami i dążeniami.

Poprzez wykonywanie zaproponowanych w podręczniku (w sekcjach „Teksty, konteksty, działania” oraz „Formy i reguły”) serii zadań pedagogicznych oraz ćwiczeń uczący się sukcesywnie nabywa wiedzę i rozwija językowe kompetencje komunikacyjne. W ten sposób przygotowuje się do realizacji celu nadrzędnego jednostki, tj. wykonania zadania głównego. Tak więc poszczególne zadania (czy podzadania) są bezpośrednio zorientowane na realizację zadania końcowego, a ich „małe" cząstkowe cele stanowią etapy osiągania celu głównego. W rozdziale ósmym podręcznika dla poziomu A2 makrozadanie (zadanie końcowe) sformułowano w następujący sposób:

\footnotetext{
${ }^{7}$ Podobnie jak w podręczniku przeznaczonym dla poziomu B1.
} 


\section{ZADANIE: ORGANIZUJEMY WYCIECZKĘ DLA KILKU OSÓB}

PRZYGOTOWANIE: W małych grupach wybierzcie miejsce, w którym moglibyście spędzić długi weekend (morze, jeziora, góry, miasta, wieś itd.). Poszukajcie informacji o tych miejscach w Internecie. Zadecydujcie, jak długo tam będziecie, czym dojedziecie do tego miejsca, gdzie będziecie spać, jeść i jak będziecie tam spędzać czas.

REALIZACJA: Opracujcie szczegółowy plan pobytu w wybranym przez was miejscu oraz listę rzeczy, które zabierzecie ze sobą.

PREZENTACJA: Zaprezentujcie swoje pomysły kolegom/koleżankom z grupy i wysłuchajcie ich opinii.

Prezentowane zadanie to sekwencja działań, które polegają na rozwiązaniu problemu i angażują uczniów w ciąg kognitywnych oraz komunikacyjnych procedur. W trakcie wykonywania zadania uczący się posługują się uprzednio i nowo nabytą wiedzą, aby wspólnie (RAZEM!) odkrywać znaczenie, realizować zaplanowane bądź wyłaniające się w toku pracy cele. Zadanie polega na przetwarzaniu danych, dokonywaniu wyboru, negocjowaniu oraz ustnym przekazywaniu informacji. Określono w nim:

- cel (goal) w kontekście jego przydatności w danej sytuacji dydaktycznej;

- materiał wejściowy (input), którym może być tekst pisany, mówiony bądź ilustracja;

- warunki wykonania zadania (conditions), czyli doprecyzowanie zasadniczych punktów w celu ukierunkowania pracy zespołu, np.: jaki zestaw informacji otrzymają uczący się, czy warunkiem pomyślnego wykonania zadania będzie wynegocjowanie wspólnego stanowiska, czy zadanie będzie wymagało interakcji, przekazania informacji etc.;

- procedury metodyczne (procedures), obejmujące zaplanowanie form pracy (w parach, w grupach, indywidulnie) oraz czasu przeznaczonego na przygotowanie i wykonanie zadania;

- przewidywany rezultat zadania (predicted outcomes), tzn. wypracowanego produktu (w formie pisemnej bądź ustnej, jego charakter - otwarty lub zamknięty) i procesów poznawczych wywołanych przez zadanie (zob. Ellis 2003, s. 21).

Czynności wykonywane w poszczególnych fazach zajęć mogą przedstawiać się następująco:

- faza przedzadaniowa (pre-task): ustne wprowadzenie do tematu, przedstawienie materiałów (mapy, foldery dotyczące miejscowości turystycznych w Polsce), odwołanie się do osobistych doświadczeń uczących się, przypomnienie słownictwa i struktur językowych, z którymi studenci już się zetknęli (chociażby w omawianej jednostce), podział na grupy; do realizacji tej fazy można śmiało wykorzystać niektóre z materiałów/zadań zaproponowanych w sekcji „Teksty, konteksty działania”; 
- faza zadaniowa (task-cycle): czytanie informacji w Interncie i oglądanie zdjęć - zapoznanie się z treścią ofert, selekcja i zapis potrzebnych informacji, przygotowanie planu pobytu i listy rzeczy do zabrania, prezentacja wyników pracy zespołów;

- faza pozadaniowa (post-task): dyskusja na forum i wybór najciekawszej oferty spędzenia długiego weekendu wraz z uzasadnieniem; analiza i wyjaśnienie trudności językowych (słownictwo, gramatyka) pojawiających się trakcie produkcji, koncentracja na formie poprzez dodatkowe ćwiczenia językowe; opinie studentów na temat zadania i pracy nad nim (np. trudności, na które napotkali podczas pracy).

Wykorzystując umiejętności nabyte w trakcie uprzednio rozwiązywanych zadań cząstkowych, podzespoły opracowują szczegółowy plan, przedstawiają go swoim kolegom z grupy, argumentując dokonane wybory. Poszczególne elementy tego złożonego zadania wyraźnie dają się zauważyć w zadaniach poprzedzających ten ostatni etap. Zadanie końcowe to rekapitulacja wiedzy i umiejętności nabytych w trakcie wykonywania zadań cząstkowych. Ponowne użycie poznanych struktur w innej sytuacji, w innym kontekście implikuje ich trwałe zapamiętanie. Nie może więc ono pozostawać w oderwaniu od tego, co było treścią jednostki, lecz jest jedynie transformacją, nowym kształtem nabytych umiejętności. Identyfikowalnym rezultatem tego zadania jest opracowane dossier, skonsultowane i przedyskutowane uprzednio z kolegami - uczestnikami wycieczki, a następnie przedstawione na forum całego zespołu.

Opisane powyżej przykłady zadań przygotowują - w swym założeniu - pod względem językowym i społecznym do radzenia sobie w kontekście pozaszkolnym, w sytuacjach życia codziennego, w których język nie jest bezpośrednim celem, ale środkiem, narzędziem niezbędnym do osiągnięcia zamierzonego rezultatu. Wykonywanie zadań to działanie w jakimś konkretnym celu - wymagające osobistego zaangażowania i aktywności, to nauka komunikacji w zaaranżowanych sytuacjach, ale skłaniająca uczącego się do komunikacji autentycznej, angażującej językowe kompetencje komunikacyjne oraz kompetencje ogólne użytkownika języka. Takie właśnie są założenia podejścia ukierunkowanego na działanie $^{8}$, zaproponowanego w Europejskim systemie opisu kształcenia językowego (2003).

\footnotetext{
${ }^{8}$ Podejście ukierunkowane na działanie/działaniowe (an action-oriented approach) to ,nowe wcielenie" podejścia komunikacyjnego, zaproponowane w oparciu o nowy cel nauczania i uczenia się języków, cel społeczny związany z integracją europejską. Ta koncepcja, jakkolwiek nowatorska, łączy cechy i dorobek wcześniejszych podejść i rozwiązań metodycznych. Podstawowymi metodami pracy lekcyjnej w obrębie podejścia ukierunkowanego na działanie są: podejście zadaniowe (oparte na wykonywaniu zadan - TBLT), podejście kompetencyjne, podejście projektowe, studium przypadku oraz symulacja globalna.
} 


\subsection{REFLEKSJA NAD JEZZYKIEM I ODKRYWANIE REGUŁ}

Celem zadań sensu largo jest nie tylko rozwiązywanie problemów o charakterze komunikacyjnym czy społecznym przy użyciu języka, ale także budzenie refleksji nad tym narzędziem komunikacji, rozwijanie świadomości językowej uczących się, automatyzacja struktur.

W zadaniowym modelu kształcenia językowego możemy mówić o dwóch podejściach do nauczania struktur językowych. Pierwsze, skrajne, odrzuca całkowicie ich nauczanie, uznając, że sama komunikacja stanowi warunek konieczny i wystarczający dla pomyślnej akwizycji języka. A drugie, bardziej umiarkowane, przyjmuje, że podsystemy języka, choć pełnią funkcję służebną wobec komunikacji, są istotnym elementem, który należy uwzględniać w procesie nauczania / uczenia się (Ellis 2003, 2009; Nunan 2004; Willis, Willis 2007).

To drugie stanowisko przyjęto w podręczniku RAZEM po polsku. Poziom A2. Zaproponowano szereg działań wymagających koncentracji na znaczeniu, jednak sporo miejsca przeznaczono także na ćwiczenia językowe - skoncentrowane na formie. Każda jednostka zawiera mocno rozbudowany komponent poświęcony rozwijaniu kompetencji leksykalnej, semantycznej i gramatycznej. Na szczególną uwagę zasługuje tu zastosowanie indukcyjnego podejścia do nauczania gramatyki, rzadko spotykanego w nauczaniu polszczyzny.

$\mathrm{W}$ analizowanej jednostce podręcznika RAZEM po polsku. Poziom A2 brak jest konkretnych sugestii odnośnie do sposobów odkrywania słownictwa. Inicjatywę pozostawiono nauczycielowi i uczniowi, licząc na to, że skorzystają oni z bogactwa struktur leksykalnych zawartych w tekstach i zadaniach zamieszczonych w sekcji „Teksty, konteksty i działania”. Tym samym podkreśla się niezastąpioną rolę kontekstu w procesie poznawania nowego słownictwa. Kontekst należy rozumieć nie tylko jako usytuowanie słowa $\mathrm{w}$ tekście, ale również $\mathrm{w}$ towarzyszących mu wszelkiego rodzaju elementach ikonograficznych (ilustracjach, planach, mapach, afiszach, itp.). Przedłużeniem tego wstępnego kontaktu ze słownictwem w tekstach i materiałach graficznych są ćwiczenia (w podręczniku i zeszycie ćwiczeń) odpowiednio ukierunkowane na systematyzację i ponowne użycie struktur, z którymi uczeń zetknął się $\mathrm{w}$ trakcie wykonywania proponowanych zadań pedagogicznych. W analizowanej jednostce metodycznej są to terminy związane z podróżami, środkami transportu, opisem osób, miejsc i czynności.

$\mathrm{Z}$ kolei procedury nauczania gramatyki zostały mocno doprecyzowane - wybrano podejście indukcyjne. Proces refleksji nad językiem stymulowany jest tekstami autentycznymi lub preparowanymi, w których dane struktury pojawiają się w czytelnym kontekście. Nauczyciel planuje działania pedagogiczne w taki sposób, by ułatwić uczącym się stopniowe odkrywanie zasad funkcjonowania systemu językowego. Kolejne etapy przyswajania struktur gramatycznych to: 
(1) wyczulenie na problem, (2) rozpoznawanie zjawiska gramatycznego, (3) weryfikacja dokonanych odkryć, (4) automatyzacja struktur i wreszcie (5) swobodne użycie języka (por. Janowska 2004). Cały proces uwzględnia autonomię ucznia i ma charakter zindywidualizowany: uczący się wyrażają swoje refleksje i spostrzeżenia w dowolny sposób.

W ósmym rozdziale podręcznika RAZEM po polsku. Poziom A2 nowo wprowadzonym zagadnieniem jest tryb warunkowy. Zagadnienie to figuruje również w spisie celów jednostki na pierwszej stronie. Konceptualizacja form odbywa się w trakcie lektury dialogów, w których wytłuszczono czasowniki w trybie warunkowym. Uczący się rozpoznają je w odpowiednio dobranych kontekstach, a następnie wpisują do specjalnie przygotowanej tabeli, której zadaniem jest uporządkowanie i klasyfikacja form. Kolejnym krokiem jest interpretacja, porównanie wyselekcjonowanych struktur w celu odkrycia zasad tworzenia trybu. Na podstawie obserwacji i podpowiedzi zamieszczonych w ćwiczeniach uczący się mogą przystąpić do ustalenia listy końcówek, werbalizacji reguł tworzenia i użycia trybu warunkowego, np.:

—Zadecyduj, czy poniższe zdania są prawdziwe (P), czy fałszywe (F).

1.Tryb warunkowy budujemy na formach czasu przeszłego. ( )

2. Tryb warunkowy budujemy na formach czasu przyszłego. ( )

3. Ważne są formy: ja/ty/my/wy. ( )

4. Ważne są tylko formy: on/ona/ono i oni/one. ( )

— Kiedy używamy trybu warunkowego? Przeczytaj zdania i odpowiedz na pytania.

a) Chciatbym z toba porozmawiać. Czy to jest propozycja/życzenie/prośba?

b) Czy powiedziałaby mi pani, gdzie jest sala 110? Czy to jest życzenie/propozycja/prośba?

c) Mam bilety do teatru, może poszłabyś ze mną? Czy to jest prośba/życzenie /propozycja?

Identyfikacji form dokonują sami uczniowie, pracując samodzielnie lub w małych zespołach. A więc muszą być wyczuleni na problem i posiadać minimalną orientację odnośnie do występowania tego zjawiska gramatycznego. Służą temu nie tylko wspomniany powyżej (specjalnie spreparowany) dialog, ale również (a może przede wszystkim) pojedyncze formy tego trybu umiejętne wkomponowane w teksty i wypowiedzi zamieszczone w części „Teksty, konteksty i działania". W ten sposób studenci oswajają się stopniowo, nawet podświadomie, z koniecznością użycia nowych struktur służących do wyrażenia życzenia czy warunku. Na tym wstępnym etapie używać mogą tylko gotowych sformułowań zaczerpniętych z materiałów, z którymi pracują. Ponadto zaproponowano jeszcze inny rodzaj „podpowiedzi” przy stosowaniu nowych struktur. W ćwiczeniu nr 2 (na wstępie rozdziału) polecenie brzmi: „Chciałbym pojechać ze znajomymi na wycieczkę, ale nie za bardzo wiem dokąd. Moglibyście coś polecić?” 
Internauci udzielają porad na podstawie przeczytanych tekstów, ale w kolejnym ćwiczeniu (nr 3) reakcje językowe studentów muszą być bardziej samodzielne, ponieważ pytanie brzmi: „Dokąd ty chciałabyś/chciałbyś pojechać na weekend”? W tworzeniu odpowiedzi uczący się mogą skorzystać z wyrażeń zamieszczonych w ramce: „chciałbym/chciałabym pojechać..., wolałbym/wolałabym pojechać..., najchętniej pojechałbym/pojechałabym..., wybrałabym się / wybrałbym się...". Tak więc wprowadzanie form trybu przypuszczającego następuje stopniowo, w kontekstach, od samego początku rozdziału, a nie tylko w części poświęconej zagadnieniom gramatycznym. Faza automatyzacji struktur i swobodnego użycia to zespół odpowiednio dobranych ćwiczeń w podręczniku (nr 5, 6, 7, 8, 9, 10, 11 - w sekcji „Formy i reguły”) oraz w zeszycie ćwiczeń. Cechuje je różnorodność zastosowanych technik: prawda/fałsz, transformacje zdań, odpowiedzi na pytania, zmiana kontekstu wymuszająca zmianę form (z trybu oznajmującego na tryb warunkowy), dokończenie rozpoczętych zdań, uzupełnianie luk, udzielanie rad typu: „co byś zrobił, gdybyś był na miejscu twego kolegi” etc.

Propozycje zamieszczone $\mathrm{w}$ tym rozdziale to lekcja indukcyjnego podejścia do nauczania gramatyki języka polskiego jako obcego. Podręcznik bazuje na aktywności uczących się, prowadząc ich przez poszczególne etapy przyswajania materiału gramatycznego. Rola nauczyciela ogranicza się do czuwania nad całym procesem. Podporządkowana celom komunikacyjnym gramatyka jest elementem umożliwiającym wykonanie poszczególnych zadań. Nie neguje się i nie pomniejsza jej znaczenia, ale mocno podkreśla jej rolę w rozwoju wiedzy proceduralnej. Gramatyka jest konieczna: pomaga, ułatwia, „skraca drogę" prowadzącą do osiągania celu i w żadnym wypadku nie jest celem sama w sobie. Jest potrzebą podyktowaną sytuacją komunikacyjną, typem zadania, któremu uczący się musi stawić czoła.

\section{PODSUMOWANIE}

Idea stosowania zadań w uczeniu się, nauczaniu i ocenianiu to centralny problem podejścia zdefiniowanego w Europejskim systemie opisu kształcenia językowego (2003). Atrybuty takiego podejścia umożliwiają pokonanie bariery między użyciem języka a jego uczeniem się, ułatwiają przejście z sali lekcyjnej do rzeczywistości pozaszkolnej i pozajęzykowej. Według twórców ESOKJ zadanie ma na celu zmobilizowanie uczących się do podejmowania działań, których efektem jest przyswajanie języka. Rozwijanie kompetencji komunikacyjnej następuje w działaniu, w trakcie wykonywania zadań. Realizacja zadań na zajęciach z języka podlega różnym uwarunkowaniom i ograniczeniom, wymaga podziału jednostek na etapy, stosowania odpowiednich strategii nauczania / uczenia się oraz form orga- 
nizacyjnych zajęć. Mając to na uwadze, twórcy serii podręczników RAZEM po polsku podjęli wyzwanie opracowania zadaniowych materiałów nauczania, opartych na działaniowej koncepcji użycia języka. Od pierwszej jednostki lekcyjnej uczeń jest stopniowo wdrażany do posługiwania się żywym językiem polskim w prywatnej, publicznej i zawodowej sferze życia. Prezentowany materiał językowy jest wykorzystywany nie tylko jako model, ale przede wszystkim jako „rusztowanie" pomagające budować własne wypowiedzi. Proponowane zadania mają głównie na celu rozwijanie działań językowych i strategii użytkowników języka, ale nie zaniedbują pracy skoncentrowanej na formie.

\section{BIBLIOGRAFIA}

Bachman L., Palmer A, 1996, Language Testing in Practice: Designing and Developing Useful Language Tests, Oxford.

Bednarska D., Machowska J., Majcher-Legawiec U., Rabiej A., 2020, RAZEM po polsku. Podręcznik do nauki języka polskiego jako obcego. Poziom A2, Kraków [w druku].

Breen M., 1987, Learner contribution to task desing, w: C. Candlin, D. Murphy (red.), Language Learning Task, London, s. 23-46.

Bucko D., Prizel-Kania A., Rogala D., 2020, RAZEM po polsku. Podręcznik do nauki języka polskiego jako obcego. Poziom B1, Kraków [w druku].

Bygate M., Skehan P., Swain M., 2001, Introduction, w: M. Bygate, P. Skehan, M., Swain (red.), Researching Pedagogic Tasks: Second Language Learning, Teaching, and Testing, London \& New York, s. 1-20.

Carroll J.B., 1993, Human Cognitive Abilities, New York.

Crookes G., 1986, Task Classification: A Cross-Disciplinary Review, Honolulu.

Demaizière F., Narcy-Combes J.-P., 2005, Méthodologie de la recherche didactique: nativisation, tâches et TIC, „Alsic”, t. 8, nr 1, s. 45-64.

Ellis R., 2003, Task-Based Language Learning and Teaching, Oxford.

Ellis R., 2006, The Methodology of Task-Based Teaching, „Asian EFL Journal”, nr 8(3), s. 19-45.

Ellis R., 2009, Task-based language teaching: sorting out the misunderstandings, „International Journal of Applied Linguistics", t. 19, nr 3, s. 221-246.

ESOKJ - Europejski system opisu ksztatcenia językowego: uczenie się, nauczanie, ocenianie, 2003, Warszawa.

Janowska I., 2004, Refleksyjne nauczanie gramatyki, „Języki Obce w Szkole”, nr 6, s. 40-48.

Janowska I., 2011, Podejście zadaniowe do nauczania i ucznia się języków obcych. Na przyktadzie języka polskiego jako obcego, Kraków.

Janowska I., 2019, Wypowiedź ustna $w$ dydaktyce językowej. Na przykladzie języka polskiego jako obcego, Kraków.

Janowska I., Rabiej A., 2014, Zadanie jako forma wspierania refleksyjnego nauczania gramatyki, „Neofilolog”, nr 43/2, s. 235-247.

Kruszewski K., 2005, Sztuka nauczania. Czynności nauczyciela, Warszawa.

Long M., 1985, Input and Second Language Acquisition Theory, w: S. Gass, C. Madden (red.), Input in Second Language Acquisition, Rowley, s. 377-393.

Long M., 1991, Focus on form: A design feature in language teaching methodology, w: K. De Bot, R. Ginsberg, C. Kramsch (red.), Foreign language research in cross-cultural perspective, Amsterdam, s. 39-52. 
Nissen E., 2011, Variations autour de la tâche dans l'enseignement/apprentissage des langues aujourd'hui, „Alsic”, nr 14, http://alsic.revues.org/2344 [dostęp: 20.05.2020].

Nunan D., 1989, Designing Tasks For The Communicative Classroom, Cambridge.

Nunan D., 2004, Task-Based Language Teaching, Cambridge.

Prabhu N.S., 1987, Second Language Pedagogy, Oxford.

Prizel-Kania A. 2013, Rozwijanie sprawności rozumienia ze stuchu w języku polskim jako obcym, Kraków.

Richards J.C., 2006, Communicative Language Teaching Today, Cambridge.

Richards J.C., Rodgers T., 2001, Approaches and Methods in Language Teaching, New York.

Samuda V., Bygate M., 2008, Tasks in second language learning, New York.

Skehan P., 1998, A Cognitive Approach to Language Learning, Oxford.

Willis D., Willis J., 2007, Doing Task-based Teaching, Oxford.

Willis J., 1996, A Framework for Task-Based Learning, London.

Iwona Janowska

\section{TASK-BASED LANGUAGE TEACHING CONCEPT IN MATERIALS FOR TEACHING POLISH AS A FOREIGN LANGUAGE}

Keywords: teaching materials, task, task-based language teaching, foreign language teaching, teaching Polish as a foreign language

Abstract. At the end of the last century, as part of the communicative methodology, there arose the need to adapt foreign language teaching system to the requirements of the changing reality. The Council of Europe's Common European Framework of Reference for Languages (2001) presented a new vision of communication and a new approach to the competence of language users: communication is an activity. Thence, the concept of an action-oriented approach originated. This approach proposes a specific way of developing communication skills which involves performing tasks embedded in environmental and situational contexts. The principles of task-based teaching and learning have been penetrating the didactics of Polish as a foreign language for several years. Unfortunately, despite the rather well-developed theoretical base of the activity-oriented and task-based approach, there is still a lack of comprehensive practical materials and textbooks that propagate the assumptions of European language policy in Polish language glottodidactics. This article shows how to apply a task-based approach in teaching practice. The concept of task-based textbooks created at the Jagiellonian University's Centre for Polish Language and Culture in the World, which is part of the latest trends in contemporary glottodidactics, is presented. The idea behind the textbooks corresponds to the need to teach a living, authentic language, which is primarily a tool for performing various social tasks. 